\section{PENEGAKAN HUKUM ATAS TINDAK PIDANA PENCURIAN YANG DILAKUKAN OLEH ANAK DI BAWAH UMUR ${ }^{1}$ \\ Oleh : Pingkan V. Tambalean ${ }^{2}$}

\begin{abstract}
ABSTRAK
Anak seyogyanya dipandang sebagai aset berharga suatu bangsa dan negara di masa mendatang yang harus dijaga dan dilindungi hak-haknya. Perlindungan hukum bagi anak dapat diartikan sebagai upaya perlindungan hukum terhadap berbagai kebebasan dan hak asasi anak serta berbagai kepentingan yang berhubungan dengan kesejahteraan anak. Akhir-akhir ini fenomena yang terjadi di masyarakat menunjukkan tindak pidana yang dilakukan oleh anak mengalami peningkatan dari waktu-kewaktu sebagaimana seringkali diberitakan baik dalam media cetak maupun media elektronik tentang berbagai peristiwa kejahatan yang pelakunya adalah anak-anak.

Pencurian yang dilakukan oleh anak di bawah umur mungkin dapat diterjemahkan sebagai pencurian khusus, yaitu sebagai suatu pencurian dengan cara-cara tertentu sehingga bersifat lebih ringan, namun dalam ketentuan hukum pidana dapat saja diancam dengan hukuman yang maksimumnya lebih tinggi, yaitu lebih dari hukuman penjara lima tahun atau lebih dari pidana yang diancamkan dalam Pasal 362 KUHP.
\end{abstract}

Oleh karena itu dalam melaksanakan pemeriksaan terhadap anak sebagai pelaku tindak pidana, haruslah diperhatikan tentang tujuan peradilan anak. Yaitu melakukan koreksi dan rehabilitasi, sehingga anak dapat kembali ke kehidupan yang normal dan mandiri demi potensi masa depannya.

Kata Kunci : Anak, Tindak Pidana Pencurian, Peradilan Anak.

\footnotetext{
${ }^{1}$ Artikel Skripsi

${ }^{2}$ NIM 090711208
}

\section{A. Pendahuluan}

Anak merupakan aset bangsa sebagai bagian dari generasi muda yang berperan strategis dalam kemajuan suatu bangsa. Peran strategis ini disadari oleh masyarakat Internasional untuk melahirkan suatu konvensi yang intinya berhak mendapatkan perlindungan atas hak-hak yang dimilikinya. Pada tahun 1990 lahirlah konvensi hak anak (Convention On The Right Of Childen) yang telah diratifikasi oleh 192 Negara termasuk Indonesia. Ratifikasi terhadap konvensi tersebut dilaksanakan melalui kepres No.36 tahun 1990 tentang Pengesahan Convention On The Right Of Children. Konsekuensi dari hal tersebut yaitu Indoneia harus memajukan serta melindungi kepentingan hak-hak anak sebagai subyek hukum seutuhnya. Dalam konvensi tersebut terdapat prinsip umum yang harus diberlakukan terhadap anak yaitu prinsip non diskriminatif, yaitu setiap manusia tidak terkecuali anak memiliki perbedan satu sama lain.. Hal ini tertera pada pasal 2 ayat 1 konvensi Hak Anak yang meyatakan :. "Negara-negara peserta (states parties) akan menghormati dan menjamin hak-hak yang telah di tetapkan dalam konvensi ini terhadap setiap anak dalam wilayah hukum mereka tanpa diskriminasi dalam bentuk apapun, tanpa memandang ras, warna kulit, jenis kelamin, bahasa, agama, pandangan politik, asalusul, sosial, harta kekayaan, cacat, kelahiran atau status lain dari anak atau orang tua atau walinya yang sah menurut hukum" Oleh karena itu Negara sudah sepantasnya menjadi pelindung utama sekaligus penjamin terlindunginya semua anak dari segala bentuk diskriminasi yang dilakukan oleh siapun juga. Seperti di sebutkan dalam ayat 2 konvensi Hak Anak.

Sementara pasal-pasal lainnya dalam konvensi hak anak yang erat kaitannya dengan perlindungan hak-hak anak yaitu : 
1. Pasal 9 ayat (1) dan (3) mengatur mengenai pemisahan anak dari orang tuanya.

2. Pasal 20 mengatur mengenai anak yang kehilangan lingkungan keluarganya baik secara tetap maupun sementara.

3. Pasal 40 ayat (2) huruf (b) mengatur mengenai jaminan hukum kepada anak yang dituduh melanggar hukum.

Dunia anak kini di pentas percaturan masyarakat dunia di berbagai forum, abaik dalam lingkungan nasional, regional, maupun internasional. Permsalahan anak semakin mononjol. Dalam masa krisis pada akhir 1990-an di Indonesia, persalahan anak makin tampil. Justru permsalahan politik dan ekonomi yang menjadi arus utama krisis multidimensi yang dihadapi oleh bangsa Indonesia, menempatkan permasalahan anak sedemikian mennjol, baik dari segi kualitas maupun kuantitas. ${ }^{1}$

Akhir-akhir ini fenomena yang terjadi di masyarakat menunjukkan tindak pidana yang dilakukan oleh anak mengalami peningkatan dari waktu-kewaktu sebagaimana seringkali diberitakan baik dalam media cetak maupun media elektronik tentang berbagai peristiwa kejahatan yang pelakuknya adalah anakanak. Penyimpangan perilaku melanggar hukum yang dilakukan anak di sebabkan berbagai faktor. Antara lain dampak negatif dari perkembangan pembangunan yang cepat, arus globalisasi di bidang komunikasi dan informasi, kemajuan IPTEK, serta perubahan gaya hidup telah membawa perubahan sosial yang mendasar dalam kehidupan masyarakat. Sehingga akan sangat berpengaruh pada nilai dan perilaku anak. Selain itu anak yang kurang atau tidak memperoleh bimbingan kasih sayang, pembinaan dalam pengembangan sikap dan perilaku, penyesuaian diri serta

\footnotetext{
${ }^{1}$ Tri Budiardjo, ., Anak-Anak; Generasi Terpingirkan, (membangun Karakter Generasi Baru Lewat Pelayanan Anak)., Penerbit Andi, Yogyakarta, 2010, hal 110.
}

pengawasan dari orang tua, wali atau orang tua asuh akan menyebabkan anak mudah terseret pada pergaulan yang kurang sehat. Sehingga akan merugikan perkembangan pribadinya. Bahkan hal tersebut dapat membuka peluang bagi anak untuk melakukan tindak pidana. Walaupun anak dapat menentukan sendiri langkah dan perbuatannya berdasarkan pikiran, perasaan dan kehendaknya, akan tetapi keadaan lingkungan disekitarnya dapat mempengaruhi perilakunya. Diantaranya adalah perilaku untuk berbuat jahat.

Menurut informasi BPS hingga akhir 2003 terdapat 136.000 anak yang berkonfllik dengan hukum dan setiap tahunnya sedukitnya 400 kasus pelanggaran hukum dilakukan oleh anak. ${ }^{2}$ Data ini belum signifikan bila dikaitkan dengan konflik hukum yang pelakunya adalah anak-anak. Karena kasus yang tercatat hanyalah kasus-kasus yang berhasil ditangani pihak Kepolisian dan Pengadilan. Padahal masih banyak perilaku anak nakal yang mengganggu lingkungan sosial tetapi tidak mencuat ke permukaan. Dari data tersebut di atas menunjukan bahwa problema anak yang melakukan tindak pidana ternyata cukup besar dan sungguh memprihatinkan. Sedangkan pada pemeriksaan di tingkat Pengadilan sering kali hak-hak terdakwa untuk memperoleh bantuan hukum tidak terpenuhi. Terutama terdakwa anak dari golongan ekonomi lemah tidak bisa mengajukan banding atau kasasi atas perkara mereka. ${ }^{3}$ Salah satu bentuk pelanggaran terhadap anak adalah adanya perlakuan buruk terhadap anak yang melakukan tindak pidana. Padahal seharusnya hak-hak anak sebagai pelaku tindak pidana juga perlu mendapatkan

\footnotetext{
2 Lily Rikantono, Dua tahun UU perlindungan anak Pelaksaan Masih Jauh Dari Harapan.Http/www. Hukum online.com (diakses tgl 5 juli 2007)

3 Sanggar Anak Akar, Segera Benahi sistem pendidikan anak, Http/www.Hukum online.com (diakses tgl 5juli 2007)
} 
perhatian yang serius dari berbagai pihak yang terkait. Karena anak yang melakukan tindak pidana juga berhak atas perlindungan dari segala bentuk diskriminasi dalam hukum. Hak atas jaminan pelarangan penyiksaan anak dan hukuman yang tidak manusiawi. Hak atas hukum acara Peradilan anak. Hak untuk memperoleh bantuan hukum baik di dalam maupun di luar Pengadilan dan sebagainya.

Putusan hakim akan mempengaruhi kehidupan anak sebagai pelaku tindak pidana. Oleh sebab itu hakim harus yakin bahwa putusan yang akan diambil akan dapat menjadi salah satu dasar kuat untuk mengembalikan dan mengantar anak menuju masa depan yang lebih baik dan untuk mengembangkan dirinya sebagai warga yang bertanggungjawab bagi keluarga, bangsa dan negara. Hal ini harus diperhatikan oleh hakim sebagai aparat penegak hukum dalam menangani kasus tindak pidana yang dilakukan oleh anak. Oleh karena itu dalam melaksanakan pemeriksaan terhadap anak sebagai pelaku tindak pidana, haruslah diperhatikan tentang tujuan peradilan anak. Yaitu melakukan koreksi dan rehabilitasi, sehingga anak dapat kembali ke kehidupan yang normal dan mandiri demi potensi masa depannya. ${ }^{4}$ Hal ini tentunya akan berpengaruh terhadap cara penanganan kasus anak. Karena para petugas Peradilan yang ada di dalam Peradilan anak belum sepenuhnya memiliki perspektif anak. Yang terpenting adalah bagaimana cara mendidik anak dalam proses penyelesaian konflik dengan hukum. Dengan demikian implementasi dari UU No.3 Tahun 1997 Tentang Pengadilan anak diharapkan dapat memberikan arah yang tepat dalam memberikan pembinaan dan perlindungan terhadap anak sebagai pelaku tindak pidana. Serta dapat menjadi wadah hukum

\footnotetext{
${ }^{4}$ Sri Widowati Soekanto,. Anak dan Wanita Dalam Hukum, Jakarta, LP 3 ES, 1984, hal 13.
}

yang lebih responsif terhadap kebutuhan anak-anak yang dipidana.

\section{B. PERUMUSAN MASALAH}

1. Bagaimana peraturan yang mengatur tindak pidana pencurian yang dilakukan oleh anak di bawah umur?

2. Bagaimana penerapan sanksi dalam menjatuhkan pidana terhadap anak di bawah umur yang melakukan tindak pidana pencurian?

\section{METODE PENELITIAN}

Penelitian merupakan suatu sarana pokok dalam pengembangan ilmu pengetahuan maupun teknologi. ${ }^{5} \mathrm{Hal}$ ini disebabkan karena penelitian bertujuan untuk mengungkapkan kebenaran secara sistematis, metodologi dan konsisten. Melalui proses penelitian tersebut diadakan analisa dan kontruksi data yang telah dikumpulkan dan diolah. Oleh karena penelitian merupakan suatu sarana ilmiah bagi pengembangan ilmu pengetahuan dan tehnologi, maka metodologi penelitian yang diterapkan harus senantiasa disesuaikan dengan ilmu pengetahuan yang menjadi induknya.

1.Spesifikasi Penelitian.

a. Jenis Penelitian.

Jenis penelitian yang dilakukan dalam penyusunan skripsi ini adalah gabungan antara yuridis normatif dan empiris. Penelitian ini disebut yurudis normatif adalah ditinjau dari objek penelitian adalah hukum positif yang mengkaji kaidah-kaidah hukum yang mengatur pemidanaan terhadap seorang anak yang di bawah umur melakukan tindak pidana pencurian.

b. Sifat Penelitian.

Sifat penelitian yang dilakukan dalam penyusunan skripsi ini adalah bersifat deskriptif analisis dalam penelitian ini tidak

\footnotetext{
5 Soejono Soekanto dan Sri Mamuji, Penelitian Hukum Normatif Suatu Tinjauan Singkat, CV.Rajawali, Jakarta, 1990, hal 1.
} 
hanya ditujukan untuk mendeskripsikan penerapan hukum pidana terkait dengan tindak pidana yang dilakukan oleh seorang anak yang masih di bawah umur.

\section{c. Pendekatan.}

Hasil suatu penelitian normatif agar lebih baik nilainya atau untuk lebih tepat penelahan dalam penelitian tersebut, peneliti perlu menggunakan pendekatan hukum dalam setiap analisisnya, pendekatan ini akan dapat menentukan nilai dari hasil penelitian tersebut. Penelitian ini adalah penelitian yuridis normatif dan yuridis empiris maka pendekatan yang dilakukan adalah pendekatan perundang-undangan, karena yang akan diteliti adalah berbagai aturan hukum yang menjadi fokus sekaligus tema sentral suatu penelitian. Analisis hukum yang dihasilkan oleh suatu penelitian normatif dengan menggunakan pendekatan perundang-undangan akan menghasilkan penelitian yang lebih akurat . Dalam penelitian digunakan pendekatan terhadap hirarki perundang-undangan yang mengatur penerpan pidana terhadap anak di bawa umur.

\section{Sumber Data Penelitian}

Memperhatikan ketentuan pidana terhadap seorang anak yang melakukan tindak pidana yang masih di bawa umur. Pada penelitian hukum normatif bahan pustaka merupakan data dasar yang dalam (ilmu) penelitian digolongkan sebagai data sekunder. ${ }^{6}$

Dalam penelitian yuridis normatif data sekunder bersumber dari : Bahan hukum primer antara lain:

a. Kitab Undang - Undang Hukum Pidana (KUHP).

b. Undang - Undang Nomor 3 tahun 1997 tentang Pengadilan Anak.

\footnotetext{
${ }^{6}$ Soerjono Soekanto dan Sri Mamuji, Ibid, hal 28
}

c. Kitab Undang - Undang Hukum Acara Pidana ( UU No 8 Tahun 1981)

Bahan hukum sekunder berupa bukubuku yang berkaitan dengan sistem pemidanaan, pembinaan narapidana, rehabilitasi dan narkotika, hasil-hasil penelitian, laporan-laporan, artikel-artikel dan seminar yang relevan dengan penelitian ini.

Bahan hukum tersier atau bahan hukum penunjang yang mencakup bahan yang memberi petunjuk-petunjuk dan penjelasan-penjelasn terhadap bahan hukum primer dan bahan hukum sekunder seperti kamus hukum, majalah dan jurnal ilmiah serta bahan-bahan di luar bidang hukum yang relevan dan dapat untuk melengkapi data yang diperlukan dalam penelitian.

\section{Alat Pengumpulan Data.}

Pengumpulan data dalam penelitian skripsi ini menggunakan studi dokumen dimana seluruh data sekunder yang dipergunakan dalam penelitian ini, dikumpulkan dengan mempergunakan studi pustaka (library research).

\section{Analisis Data}

Data yang diperoleh dalam penelitian ini akan dianalisis secara kualitatif sesuai dengan spesifikasi sifat penelitian untuk mengkaji antara teori dan praktek dalam pelaksanaan rehabilitasi di Lembaga Pemasyarakatan sebagai bagian pembinaan dengan sistem pemasyarakatan. Analisis data kualitatif adalah dengan melakukan penggalian fakta-fakta sosial tidak hanya yang tampak dipermukaan namun justru menggali apa yang sesungguhnya terjadi dibalik peristiwa nyata tersebut. Penarikan kesimpulan akan diperoleh dari penyelesaian perumusan masalah yang dilakukan dalam penelitian.

\section{TINJAUAN PUSTAKA}




\section{Pengertian Tentang Anak Yang Bermasalah Dengan Hukum}

Apabila ditinjau dari aspek yuridis, maka pengertian "anak" dimata hukum positif Indonesia lazim diartikan sebagai orang yang belum dewasa (minderjaring atau person under age), orang yang di bawah umur atau keadaan di bawah umur (minderjaringheid atau inferionity) atau kerap juga disebut sebagai anak yang di bawah pengawasan wali (minderjarige onvervoodij). ${ }^{1}$ Pada tingkat Internasional rupanya tidak terdapat keseragaman dalam perumusan batasan tentang anak, tingkatan umur seseorang dikategorikan sebagai anak anatara satu negara dengan negara lain cukup beraneka ragam yaitu :

Menurut Pasal 1 Konvensi Anak merumuskan pengertian anak sebagai "setiap manusia yang berusia dibawah 18 tahun kecuali berdasarkan Undang-undang yang berlaku bagi anak ditentukan bahwa usia dewasa dicapai lebih awal".

Berbagai kriteria untuk batasan usia anak pada dasarnya adalah pengelompokan usia maksimum sebagai perwujudan kemampuan seorang anak dalam status hukum sehingga anak tersebut akan beralih status menjadi usia dewasa atau menjadiseorang subyek hukum yang data bertanggungjawab secara mandiri terhadap perbuatan-perbuatan dan tindakan-tindaka hukum yang dilakukan oleh anak itu. ${ }^{5}$

Beberapa hal yang perlu diperhatikan bahwa indikator untuk mengatakan bahwa seseorang telah dikatakan telah dewasa adalah bahwa ia dapat melakukan perbuatan hukum sendiri tanpa bantuan orang lain baik orang tua maupun wali. Berdasarkan penjelasan-penjelasan beberapa peraturan perundang-undangan diatas, maka dapat dilihat bahwa

\footnotetext{
${ }^{1}$ Lilik Mulyadi,. Pengadilan Anak Di Indonesia, (Teori Praktek dan Permsalahannya) CV.Mandar Maju, Bandung, 2005, hal. 3-4

5 Maulana Hasan Wadong, Advokasi Dan Hukum Perlindungan Anak, Grasindo, Jakarta, 2000, hal.24.
}

pengertian anak adalah bervariatif dimana hal tersebut dilihat dari pembatasan batas umur yang diberikan kepada seorang anak apakah anak tersebut dibawah umur atau belum dewasa dan hal tersebut dapat dilihat dari pengertian masing-masing peraturan perundang-undangan yang berlaku di Indonesia, Namun meskipun demikian pada prinsipnya anak dibawah umur adalah seseorang yang tumbuh dalam perkembangannya yang mana anak tersebut memerlukan bimbingan untuk kedepannya.

Hukum internasional telah menetapkan standar perlakuan yang harus atau dapat dirujuk oleh setiap negara dalam menangani anak yang berhadapan dengan hukum. Hukum internasional mensyaratkan negara untuk memberikan perlindungan hukum dan penghormatan terhadap anak yang berhadapan dengan hukum melalui pengembangan hukum, prosedur, kewenangan, dan institusi (kelembagaan).

Secara konseptual anak yang berhadapan dengan hukum (children in conflict with the law), dimaknai sebagai : Seseorang yang berusia di bawah 18 tahun yang berhadapan dengan sistem peradilan pidana dikarenakan yang bersangkutan disangka atau dituduh melakukan tindak pidana.

Anak yang berhadapan dengan hukum adalah anak yang telah mencapai usia 12 (dua belas) tahun tetapi belum mencapai usia 18 (delapan belas) tahun dan belum menikah yaitu :

1) Yang diduga, disangka, didakwa, atau dijatuhi pidana karena melakukan tindak pidana;

2) Yang menjadi korban tindak pidana atau yang melihat dan/atau mendengar sendiri terjadinya suatu tindak pidana.

Anak yang berhadapan dengan hukum dapat juga dikatakan sebagai anak yang terpaksa berkontak dengan sistem pengadilan pidana karena: 
1) Disangka, didakwa, atau dinyatakan terbukti bersalah melanggar hukum; atau

2) Telah menjadi korban akibat perbuatan pelanggaran hukum yang dilakukan orang/kelompok orang/lembaga/negara terhadapnya; atau

3) Telah melihat, mendengar, merasakan, atau mengetahui suatu peristiwa pelanggaran hukum.

Dilihat ruang lingkupnya maka anak yang berhadapan dengan hukum dapat dibagi menjadi :

1) Pelaku atau tersangka tindak pidana;

2) Korban tindak pidana;

3) Saksi suatu tindak pidana.

Menurut Pasal 1 huruf 2 UndangUndang No.3 Tahun 1997 tentang Pengadilan Anak, terdapat dua kategori perilaku anak yang dapat membuat seorang anak berhadapan dengan hukum yakni status offences dan criminal offences. Status offences adalah perilaku kenakalan anak yang apabila dilakukan orang dewasa tidak termasuk kejahatan atau anak yang melakukan perbuatan terlarang bagi seorang anak. Misalnya, tidak menurut, membolos sekolah, kabur dari rumah, sedangkan criminal offences adalah perilaku kenakalan anak yang apabila dilakukan orang dewasa termasuk kategori kejahatan atau anak yang bermasalah dengan hukum. ${ }^{6}$

\section{Proses Penanganan Terhadap Anak yang Melakukan Tindak Pidana}

Proses peradilan adalah suatu proses yuridis, dimana harus ada kesempatan orang berdiskusi dan dapat memperjuangkan pendirian tertentu yaitu mengemukakan kepentingan oleh berbagai macam pihak, mempertimbangkannya dan dimana keputusan yang diambil tersebut mempunyai motivasi tertentu. ${ }^{12}$ Seperti

\footnotetext{
${ }^{6}$ Maulana Hasan Wadong, Ibid, hal 25.

12 Shanty Dellyana,. Wanita Dan Anak Dimata Hukum, Liberty, Yogyakarta, 1988, hal.57.
}

halnya orang dewasa, anak sebagai pelaku tindak pidana juga akan mengalami proses hukum yang identik dengan orang dewasa yang melakukan tindak pidana, arti kata identik disini mengandung arti "hampir sama", yang berbeda hanya lama serta cara penanganannya.

Penanganan anak dalam proses hukumnya memerlukan pendekatan, pelayanan, perlakuan, perawatan serta perlindungan yang khusus bagi anak dalam upaya memberikan perlindungan hukum terhadap anak yang berhadapan dengan hukum.

Proses penanganan anak yang berhadapan dengan hukum erat kaitannya dengan penegakan hukum itu sendiri, dimana dalam Sistem Peradilan Pidana Anak (juvenile justice system). Dikaji dari perspektif Sistem Peradilan Pidana (Criminal Justice System) maka di Indonesia dikenal 5 (lima) institusi yang merupakan sub Sistem Peradilan Pidana. Terminologi lima institusi tersebut dikenal sebagai Pnca Wangasa penegak hukum, yaitu Lembaga Kepolisian, Kejaksaan, Pengadilan, Lembaga Pemasyarakatan dan advokat. ${ }^{14}$

Proses (pelaksanaan penegakan hukum) pidana merupakan suatu bentuk pemeriksaan yang dilakukan menurut tatacara yang ditentukan oleh undangundang (Pasal 3 KUHAP), Undang-undang ini menentukan hak-hak dan kewajibankewajiban mereka yang ada dalam proses dimana pelaksanaan dan hak dan kewajiban mereka itu menjadi intinya proses. $^{16}$

Perlindungan hukum terhadap anak dalam proses peradilan dilakukan dimulai semenjak tingkat penyelidikan, penyidikan, penuntutan, pemeriksaan di sidang pengadilan sampai pada pelaksanaan

\footnotetext{
14 Lilik Mulyadi, Kompilasi Hukum Pidana Dalam Perspektif Teoritis dan Praktik Peradilan, Penerbit Mandar Maju, Bandung, 2010, hal. 56.

${ }^{16}$ Soedirdjo,. Jaksa Dan Hakim Dalam Proses Pidana, Akademika Presindo, Jakarta, 1985, hal 2.
} 
putusan pengadilan tersebut. Selama proses peradilan tersebut, maka hak-hak anak wajib dilindungi oleh hukum yang berlaku dan oleh sebab itu harus dilakukan secara konsekuen oleh pihak-pihak terkait dengan penyelesaian masalah anak nakal tersebut. Adapun hal-hal yang harus diperhatikan dalam proses penanganan anak yang berhadapan dengan hukum adalah :

\section{E. PEMBAHASAN}

1. Tinjauan Umum Terhadap Pembedaan Tindak Pidana Pencurian

Dalam Pasal 362 KUHPidana merupakan pasal di mana dirumuskan bentuk pokok dari pencurian. Pasal-Pasal lainnya mengandung unsur tambahan terhadap pencurian dalam bentuk pokok (pasal 362 KUHpidana). Dengan mempelajari rumusan Pasal-pasal 362, 363, 364, 365, dan 367 KUHPidana, maka terhadap perbuatanperbuatan pencurian tersebut dibuat klasifikasi sebagai berukut:

1. Pencurian dalam bentuk pokok ( Pasal 362);

2. Pencurian yang dukualifikasi/dierberat ( Pasal 363

3. Pencurian ringan (Pasal 363)

4. Pencurian dengan kekerasan (Pasal 365)

5. Pencurian dalam keluarga ( 367 )

Pencurian yang dilakukan oleh anak di bawah umur mungkin dapat diterjemahkan sebagai pencurian khusus, yaitu sebagai suatu pencurian dengan cara-cara tertentu sehingga bersifat lebih ringan, namun dalam ketentuan hukum pidana dapat saja diancam dengan hukuman yang maksimumnya lebih tinggi, yaitu lebih dari hukuman penjara lima tahun atau lebih dari pidana yang diancamkan dalam Pasal 362 KUHP. Hal ini diatur dalam Pasal 363 dan Pasal 365 KUHP.

\section{- Pasal 363 KUHP}

(1) Dihukum dengan hukuman penjara selama-lamanya tujuh tahun :
(2) Jika pencurian yang dterangkan dalam butir 3 disertai dengan salah satu hal dalam 4 dan 5, maka diancam dengan pidana penjara paling lama sembilan tahun.

- Pasal 365 KUHP

(1) Dengan hukuman penjara selamalamanya sembilan tahun dihukum pencurian yang didahului, disertai, atau diikuti dengan kekerasan atau ancaman kekerasan terhadap orang lain, dengan maksud untuk mempersiapkan atau memudahkan pencurian itu, atau si pencuri jika tertangkap basah, supaya ada kesempatan bagi dirinya sendiri atau bagi yang turut serta melakukan kejahatan itu untuk melarikan diri atau supaya barang yang dicuri tetap tinggal di tangannya.

(2) Hukuman penjara selama-lamanya dua belas tahun

(3) Dijatuhkan hukuman penjara selama-lamanya lima belas tahun jika perbuatan itu berakibat matinya orang;

(4) Hukuman mati atau hukuman penjara seumur hidup atau penjara selam-lamanya dua puluh tahun dijatuhkan jika perbuatan itu berakibat ada orang luka berat atau mati, dan lagi perbuatan itu dilakukan bersama-sama oleh dua orang atau lebih, dan lagi pula disertai salah satu dari hal-hal yang disebutkan dalam nomor 1 dan nomor 2 .

Unsur yang memberatkan dalam Pasal 363 dan Pasal 365 KUHP adalah :

1. Pencurian Ternak

2. Pencurian pada waktu ada kebakaran, letusan, banjir, gempa bumi, gunung meletus, kapal karam, kapal terdampar, kecelakaan kereta api, huru-hara, pemberontakan atau 
bahaya perang (Pasal 363 ayat (1) ke-2 KUHP).

3. Pencurian di waktu malam dalam sebuah rumah atau pekarangan tertutup yang ada rumahnya, yang dilakukan oleh orang yang ada di situ tidak diketahui atau dikehendaki oleh yang berhak (Pasal 363 ayat (1) ke-3 KUHP).

4. Pencurian yang dilakukan oleh dua orang atau lebih dengan bersekutu (Pasal 363 ayat (1) ke-4 KUHP).

5. Pencurian dengan jalan membongkar, merusak, dan sebagainya (Pasal 363 ayat (1) ke-5 KUHP).

- Pasal 365 KUHP

Unsur-unsur yang terdapat di dalam Pasal 365 KUHP ayat (1) KUHP, adalah

1. Pencurian;

2. Didahului atau disertai atau diikuti;

3. Kekerasan atau ancaman kekerasan;

4. Terhadap orang;

5. Dilakukan dengan maksud:

a. Mempersiapkan atau;

b. Memudahkan atau;

c. Dalam hal tertangkap tangan;

d. Untuk memungkinkan melarikan diri bagi dirinya atau peserta lain; e. Untuk menjamin tetap dikuasainya barang yang dicuri.

Unsur-unsur yang terdapat di dalam Pasal 365 ayat (2) ke-1 KUHP, adalah :

1. Waktu malam;

2. Dalam sebuah rumah atau pekarangan tertutup yang ada rumahnya;

3. Di jalan umum;

4. Dalam kereta api atau trem yang sedang berjalan.

Unsur-unsur yang terdapat di dalam Pasal 365 ayat (2) ke-2 KUHP, adalah :

1. Dua orang atau lebih;

2. Bersama-sama.

Unsur-unsur yang terdapat di dalam Pasal 365 ayat (2) ke-3 KUHP, adalah :
1. Didahului, disertai, atau diikuti;

2. Kekerasan atau ancaman kekerasan;

3. Dengan maksud mempersiapkan;

4. Dengan cara membongkar, merusak, memanjat, atau;

5. Menggunakan anak kunci palsu, perintah palsu, seragam palsu.

Unsur-unsur yang terdapat di dalam Pasal 365 ayat (2) ke-4 KUHP, adalah "mengakibatkan luka berat". Pengertian luka berat diatur dalam Pasal 90 KUHP, yaitu :

1. Jatuh sakit atau mendapat luka yang tidak memberi akan sembuh sama sekali, atau menimbulkan bahaya maut.

2. Tidak mampu secara terus-menerus untuk menjalankan tugas, jabatan atau pekerjaan pencahariannya.

3. Kehilangan salah satu panca indera.

4. Mendapat cacat berat.

5. Menderita sakit lumpuh.

6. Terganggunya daya pikir selama empat minggu lebih.

7. Gugurnya atau matinya kandungan seorang perempuan.

Unsur-unsur yang terdapat di dalam Pasal 365 ayat (3) KUHP adalah :

1. Didahului, disertai atau diikuti;

2. Kekerasan atau ancaman kekerasan;

3. Mengakibatkan kematian.

Unsur-unsur yang terdapat di dalam Pasal 365 ayat (4) KUHP adalah :

1. Mengakibatkan luka berat atau;

2. Kematian;

3. Dilakukan oleh dua orang atau lebih;

4. Dengan bersekutu;

5. Disertai salah satu hal dari unsur ayat (2) ke-1 dan ke-3.

\section{Pemberian Sanksi Pidana dan Tindakan Terhadap Anak Sebagai Pelaku Tindak Pidana}

Sanksi pidana yang dapat dijatuhkan terhadap anak sebagai pelaku delik menurut UU Nomor 3 Tahun 1997 tentang 
Peradilan Anak Pasal 22 adalah pidana dan tindakan.

\section{Sanksi Pidana}

Sanksi Pidana yang dapat dijatuhkan terhadap anak sebagai pelaku delik adalah pidana pokok dan pidana tambahan, sebagai berikut:

\subsection{Pidana pokok}

Pidana pokok yang dapat dijatuhkan terhadap anak sebagai pelaku delik diatur dalam UU Nomor 3 Tahun 1997 tentang Peradilan Anak Pasal 23 ayat

(2) yaitu :

a. Pidana Penjara

Menurut Pasal 26 ayat (1) UU No. 3 Tahun 1997 berbunyi: Pidana penjara yang dapat dijatuhkan kepada anak sebagaimana dimaksud Pasal 1 angka 2 huruf a, paling lama satu perdua dari maksimum ancaman pidana penjara bagi orang dewasa.

Menurut Pasal 26 ayat (2) UU No. 3 Tahun 1997 berbunyi: Apabila anak nakal sebagaimana dimaksud Pasal 1 angka 2 huruf a, melakukan delik yang diancam dengan pidana mati atau pidana penjara seumur hidup, maka pidana penjara yang dapat dijatuhkan kepada anak tersebut paling lama sepuluh tahun.

Menurut Pasal 26 ayat (3) UU No. 3 Tahun 1997 berbunyi: Apabila anak nakal sebagaimana dimaksud Pasal 1 angka 2 huruf a, belum mencapai umur 12 tahun melakukan delik yang diancam pidana mati atau pidana penjara seumur hidup, maka terhadap anak nakal tersebut hanya dapat dijatuhkan tindakan sebagaimana dimaksud dalam Pasal 24 ayat (1) huruf b yaitu menyerahkan kepada negara untuk mengikuti pendidikan, pembinaan dan latihan kerja.

Menurut Pasal 26 ayat (4) UU No. 3 Tahun 1997 berbunyi: Apabila anak nakal sebagaimana dimaksud Pasal 1 angka 2 huruf a, belum mencapai umur 12 tahun melakukan delik yang diancam pidana mati atau pidana penjara seumur hidup, maka terhadap anak nakal tersebut dijatuhkan salah satu tindakan sebagaimana dimaksud dalam Pasal 24.

b. Pidana kurungan

Menurut Pasal 27 UU No. 3 Tahun 1997 berbunyi bahwa: Pidana kurungan yang dapat dijatuhkan kepada anak nakal sebagaimana dimaksud Pasal 1 Angka 2 Huruf a, paling lama satu perdua dari maksimum ancaman pidana kurungan bagi orang dewasa.

c. Pidana denda

Menurut Pasal 28 ayat (1) UU No. 3 Tahun 1997 berbunyi bahwa "Pidana denda yang dapat dijatuhkan kepada anak nakal paling banyak satu perdua dari maksimum ancaman pidana denda bagi orang dewasa."

Menurut Pasal 28 ayat (2) UU No. 3 Tahun 1997 berbunyi bahwa: "Apabila pidana denda sebagaimana dimaksud dalam ayat 1 ternyata tidak dapat dibayar maka diganti dengan wajib latihan kerja".

Menurut Pasal 28 ayat (3) UU No. 3 Tahun 1997 berbunyi bahwa: "Wajib latihan kerja sebagai pengganti denda dilakukan paling lama 90 hari kerja dan lama latihan kerja tidak lebih dari 4 jam sehari serta tidak dilakukan pada malam hari".

d. Pidana pengawasan

Menurut Pasal 30 ayat (1) UU No. 3 Tahun 1997 berbunyi "pidana pengawasan yang dapat dijatuhkan kepada anak nakal sebagaimana dimaksud dalam Pasal 1 angka 2 huruf a, paling singkat 3 bulan dan paling lama 2 tahun". 
Menurut Pasal 30 ayat (2) UU No. 3 Tahun 1997 berbunyi: Apabila terhadap anak nakal sebagaimana dimaksud dalam Pasal 1 angka 2 huruf a, dijatuhkan pidana pengawasan sebagaimana dimaksud dalam ayat 1 , maka anak tersebut ditempatkan di bawah pengawasan jaksa dan bimbingan pembimbing kemasyarakatan.

Menurut Pasal 30 ayat (3) UU No. 3 Tahun 1997 berbunyi "Ketentuan mengenai bentuk dan tata cara pelaksanaan pidana pengawasan diatur lebih lanjut dengan peraturan pemerintahan".

\subsection{Pidana tambahan}

Pidana tambahan yang dapat dijatuhkan terhadap anak sebagai pelaku delik diatur dalam UU Nomor 3 Tahun 1997 tentang Peradilan Anak Pasal 23 ayat (1) yaitu :

a. Perampasan barang-barang tertentu

Barang yang dapat dirampas adalah barang yang diperoleh dengan kejahatan atau barang yang dipakai untuk melakukan delik. Pada umumnya barangbarang yang boleh dirampas harus kepunyaan terhukum.

b. Pembayaran ganti rugi

Menurut mengemukakan bahwa "pembayaran ganti rugi yang dijatuhkan sebagai pidana tambahan merupakan tanggung jawab dari orang tua atau orang lain yang menjalankan kekuasaan orang tua".

\section{Sanksi Tindakan}

Sanksi Tindakan yang dapat dijatuhkan terhadap anak sebagai pelaku delik diatur dalam Pasal 24 ayat (1) UU Nomor 3 Tahun 1997 tentang Peradilan Anak sebagai berikut : a. Mengembalikan kepada orang tua, wali, atau orang tua asuh

Menurut penulis bahwa: Meskipun anak dikembalikan kepada orang tua, wali, atau orang tua asuh, anak tersebut tetap dibawah pengawasan dan bimbingan. Pembimbing Kemasyarakatan, antara lain mengikuti kegiatan kepramukaan dan lain- lain.

b. Menyerahkan kepada Negara untuk mengikuti pendidikan, pembinaan dan latihan kerja

Menurut Gatot Supramono menulis bahwa: Apabila hakim berpendapat bahwa orang tua, wali, atau orang tua asuh tidak memberikan pendidikan dan pembinaan yang lebih baik, maka hakim dapat menetapkan anak tersebut ditetapkan di Lembaga Pemasyarakatan Anak untuk mengikuti pendidikan, pembinaan dan latihan kerja. ${ }^{1}$ Latihan Kerja dimaksudkan untuk memberikan bekal keterampilan kepada anak, misalnya dengan memberikan keterampilan mengenai pertukangan, pertanian, perbengkelan, tata rias dan sebagainya setelah selesai menjalani tindakan dapat hidup mandiri.

c. Menyerahkan kepada Departemen Sosial, atau Organisasi Sosial Kemasyarakatan yang bergerak di bidang pendidikan, pembinaan, dan latihan kerja

Adapun pidana yang dapat dijatuhkan kepada si anak terdapat dalam Pasal 23 Undang-Undang Nomor 3 Taun 1997, yaitu pidana pokok dan pidana tambahan. Pidana pokok meliputi:

1) pidana penjara,

2) pidana kurungan,

3) pidana denda, dan

4) pidana pengawasan.

\footnotetext{
${ }^{1}$ Gatot Supramono, 2000, Hukum Acara Peradilan Anak, Djambatan, Jakarta, 2000, hal. 35.
} 
Pada prinsipnya pendidikan, pembinaan, dan latihan kerja diselenggarakan oleh pemerintah di Lembaga Pemasyarakatan Anak atau Departement Sosial, tetapi dalam hal kepentingan anak menghendaki hakim dapat menetapkan anak yang bersangkutan diserahkan kepada Organisasi Sosial Kemasyarakatan, seperti pesantren, panti sosial, dan lembaga sosial lainnya dengan memperhatikan agama anak yang bersangkutan.

Menurut UU Nomor 3 Tahun 1997 Pasal 24 ayat (2) berbunyi "Tindakan sebagaimana dimaksud dalam Pasal 24 ayat (1) dapat disertai dengan teguran dan syarat tambahan yang ditetapkan oleh Hakim". Dimana teguran yang dimaksud adalah peringatan dari hakim baik langsung terhadap anak yang dijatuhi tindakan maupun secara tidak langsung melalui orang tua, wali, atau orang tua asuhnya, agar anak tersebut tidak mengulangi perbuatan yang mengakibatkan anak tersebut dijatuhi tindakan.

Sedangkan maksud dari syarat tambahan adalah kewajiban untuk melapor secara periodik kepada Pembimbing Kemasayarakatan.

Tahap akhir dalam proses pemeriksaan suatu perkara adalah penjatuhan putusan akhir (vonis) oleh hakim. Hakim dalam menjatuhkan segala dakwaan maupun pelepasan dari segala tuntutan hukum harus disertai dengan pertimbangan hakim.

Adapun pertimbangan hakim dalam memutuskan suatu perkara pidana dapat meliputi pertimbangan dalam hal peniadaan, peringanan maupun pemberatan pidana. Yang dimaksud dengan peringanan dan pemberatan dalam rancangan KUHPidana ialah "peringanan 1/3 (sepertiga)" atau "pemberatan 1/3 (sepertiga)" dari pidana yang diancamkan.

\section{G. PENUTUP}

1 Kesimpulan
Dari uraian tersebut diatas maka penulis dapat menyimpulkan sebagai berikut :

1. Peraturan yang mengatur tindak pidana pencurian yang dilakukan oleh anak di bawah umur sesuai dengan perbuatan yang dilakukan oleh anak tersebut yaitu memberikan sanksi pidana menurut Undang-Undang No. 3 Tahun 1997 pasal 23 ayat 2 tentang Peradilan anak. Selain itu juga sanksi tindakan menurut Undang-Undang no. 3 Tahun 1997 pasal 23 ayat 1 tentang Peradilan Anak.

2. Penerapan sanksi dalam menjatuhkan pidana terhadap anak di bawah umur yang melakukan tindak pidana pencurian, harus mempertimbangkan hal-hal yang meringankan bagi terdakwa anak yang masih di bawah umur yaitu paling lama satu per dua dari maksimum ancaman pidana penjara bagi orang dewasa, dan sanksi tindakan seperti mengembalikan kepada orang tua, wali, orang tua asuh, atau menyerahkan kepada negara untuk mengikuti pendidikan, pembinaan, dan latihan kerja. Kedua sanksi ini dianggap dapat memberikan efek jerah bagi pelaku anak di bawah umur yang melakukan tindak pidana pencurian.

\section{Saran}

Melalui skripsi ini penulis menyampaikan beberapa saran yang terkait dengan penelitian penulis antara lain :

Diharapkan kepada aparat penegak hukum agar memperhatikan aturan-aturan yang diberlakukan kepada terdakwa yang dalam hal ini dikategorikan sebagai anak di bawah umur. Sehingga ancaman-ancaman pidana penjara dan sanksi tindakan menjadi alternatif terakhir dalam memberikan sanksi bagi anak tersebut. Dan sebaiknya kepada aparat penegak hukum dan masyarakat untuk memberikan penyuluhan-penyuluhan atau sosialisasi hukum secara aktif dan menyeluruh 
khususnya kepada anak di bawah umur mengenai dampak dari pencurian yang merugikan masyarakat itu sendiri bahkan juga merugikan diri anak sendiri tersebut.

\section{DAFTAR PUSTAKA}

Andi Hamzah,. Pengantar Hukum Acara

Pidana Indonesia, Cet.5, Sinar

Grafika, Jakarta, 2006.

Abdussalam, Hukum Perlindungan Anak,

Restu Agung, Jakarta, 2007.

Departemen Pendidikan dan Kebudayaan, Kamus Besar Bahasa Indonesia, Balai Pustaka, Jakarta, 1991.

Djoko Prakoso, Kedudukan Justisiabel di dalam KUHAP, Ghalia Indonesia, Jakarta, 1986.

Gautama, Konvensi Hak Anak Panduan Bagi Jurnalis, Lembaga Studi Pers Dan Pembangunan (LSPP), Jakarta, 2000.

Harahap Yahya,. Pembahasan Permasalahan Dan Penerapan KUHAP Penyidikan Dan Penuntutan, Sinar Grafika, Jakarta, 2006.

Kartini Kartono, Pathologi Sosial( 2), Kenakalan Remaja, Rajawali Pers, Jakarta, 1992

Lilik Mulyadi,. Pengadilan Anak Di Indonesia, (Teori Praktek dan Permsalahannya) CV.Mandar Maju, Bandung, 2005.

--------., Lilik Mulyadi, Kompilasi Hukum Pidana Dalam Perspektif Teoritis dan Praktik Peradilan, Penerbit Mandar Maju, Bandung, 2010.

Romli Atmasasmita,. Peradilan Anak di Indonesia, Mandar Maju, Bandung,1997

---------.,Romli Atmasasmita, . Sistem Peradilan Pidana, Bina Cipta, Bandung,, 1996.

---------.,Romli Atmasasmita, Problem Kenakalan Anak-anak Remaja, Armico, Bandung, 1983.

Shanty Dellyana,. Wanita Dan Anak Dimata Hukum, Liberty, Yogyakarta, 1988.
Soedirdjo,. Jaksa Dan Hakim Dalam Proses Pidana, Akademika Presindo, Jakarta, 1985.

Soejono Soekanto dan Sri Mamuji, Penelitian Hukum Normatif Suatu Tinjauan Singkat, CV.Rajawali, Jakarta, 1990.

Supramono G,. Hukum Acara Pengadilan Anak, Djambatan, Jakarta, 2007.

Sri Widowati Soekanto,. Anak dan Wanita Dalam Hukum, Jakarta, LP 3 ES, 1984.

Sudarsono,. Kenakalan Remaja, Rineka Cipta, Jakarta,1991

Tri Budiardjo, ., Anak-Anak; Generasi Terpingirkan, (membangun Karakter Generasi Baru Lewat Pelayanan Anak)., Penerbit Andi, Yogyakarta, 2010

Wagiati Soetodjo., Hukumm Pidana Anak, PT. Refika Aditama, 2006.

\section{UNDANG- UNDANG :}

Kitab Undang- Undang Hukum Pidana Kitab Undang-Hukum Acara Pidana Undang- undang Nomor 3 Tahun 1997 Tentang Peradilan Anak

\section{Sumber lain :}

Lily Rikantono, Dua tahun UU perlindungan anak Pelaksaan Masih Jauh Dari Harapan.Http/www. Hukum online.com (diakses tanggal 5 juli 2007)

Sanggar Anak Akar, Segera Benahi sistem pendidikan anak, Http/www.Hukum online.com (diakses tanggal 5juli 2007, pukul 10:02 am)

Eka Smansa, Pengertian Hukum.Http/www.sasmitasmasa.wordpr ess.com (diakses tanggal 7 Desember 2007)

Ashibly, Teori Hukum.Http/www.ashibly.blogspot.com (diakses tanggal senin, 25 Juli 2011, pukul 19.25) 